cesses are responsible for the limiting current behavior of oxygen reduction on Fe-Cr alloys, while the simplest explanation may be the catalytic decomposition mechanism which claims that the peroxide-decomposing activity decreases with increasing $\mathrm{Cr}$ content.

(Received Dec. 11, 1971)

\section{References :}

1) J.P. Hoare, "The Electrochemistry of Oxygen", p. 117 (1968), Interscience Pub..
2) J.P. Hoare, "Advances in Electrochemistry and Electrochemical Engineering" Ed. by P. Delahay, Vol. 6, p. 201 (1967), Interscience Pub..

3) M. Nagayama, M. Cohen, J. Electrochem. Soc. 109, 783 (1962).

4) S. Haruyama, M. Okuyama, M. Mukai, This Journal 36, 534 (1968).

5) M. Okuyama, S. Haruyama, M. Mukai, ibid. 37, 670 (1969).

6) M. Okuyama, T. Tsuru, S. Haruyama, K. Nagasaki, ibid. 39, 8 (1971).

7) A. Damjanovic, M.A. Genshaw, J.O'M. Bockris, J. Phys. Chem. 10, 3761 (1966).

\title{
Tectnical Paper
}

\section{Phases Found in Quenched Specimens of $\mathrm{TiO}_{2}-\mathrm{CaO}$ System*}

\author{
Osamu Matsumoto**, Katsushi IshidA** and Yukio MitsuYA**
}

\begin{abstract}
$\mathrm{TiO}_{2}-\mathrm{CaO}$ system was studied by means of an arc imaging furnace. The primary heat source was a xenon arc lamp with ellipsoidal reflecting optics. The specimen of $\mathrm{TiO}_{2}$ and $\mathrm{CaO}$ mixture was set on a holder at the focus of the concentrator of the furnace and was melted by the radiation of the light beam. The specimen was quenched from the melt to the room temperature. Quenched specimens were examined by chemical analysis, X-ray diffraction method, infrared absorption spectroscopy and dielectric constant measurement. Phases found in the quenched specimens were $\mathrm{CaO} \cdot \mathrm{TiO}_{2}, 3 \mathrm{CaO} \cdot 2 \mathrm{TiO}_{2}$ and $4 \mathrm{CaO}$. $3 \mathrm{TiO}_{2}$. From the X-ray diffraction data and the infrared spectroscopic data, the existence of $\mathrm{TiO}_{6}$ octahedral configuration was confirmed in all phases. The dielectric constant of pure $\mathrm{CaO} \cdot \mathrm{TiO}_{2}$ was much higher than that of other specimens.
\end{abstract}

\section{Introduction}

An arc imaging furnace as well as a solar furnace has been proved to be useful for the heat treatment of the specimen at high temperatures.

The phase study of some binary oxides systems such as $\mathrm{ZrO}_{2}-\mathrm{CaO}^{1)}, \quad \mathrm{ZrO}_{2}-\mathrm{MgO}^{23}, \quad \mathrm{ZrO}_{2}-\mathrm{SrO}^{3)}, \mathrm{ZrO}_{2}-$ $\mathrm{TiO}_{2}{ }^{4)}, \quad \mathrm{ZrO}_{2}-\mathrm{La}_{2} \mathrm{O}_{3}{ }^{5}, \quad \mathrm{ZrO}_{2}-\mathrm{Gd}_{2} \mathrm{O}_{3}{ }^{6)}, \mathrm{Al}_{2} \mathrm{O}_{3}-\mathrm{Y}_{2} \mathrm{O}_{3}{ }^{3)}$ and $\mathrm{La}_{2} \mathrm{O}_{3}-\mathrm{Cr}_{2} \mathrm{O}_{3}{ }^{8}$ ) were reported, in which the specimens were melted by using the solar and arc imaging furnaces and then quenched from the melt.

The phase diagram on $\mathrm{TiO}_{2}-\mathrm{CaO}$ system were studied by other researchers ${ }^{9 / 10}$, however, the data on the property and the structure of the quenched specimen are scarecely reported.

In this paper, a study on the property and the structure of the quenched specimen from the melt of $\mathrm{TiO}_{2}-\mathrm{CaO}$ system, by using a xenon arc imaging fur-

\footnotetext{
* Studies of Oxides System by Means of the Are Imaging Furnace (Part 1)

Reported on 4 th Syraposium of Fused Salt Chemistry (held on November 1970 at Tokyo)

** Department of Chemistry, College of Science and Engineering, Aoyama Gakuin University (6-16-1, Chitosedai, Setagaya-ku, Tokyo)
}

nace to attain the high temperatures, is reported.

\section{Experimentals}

\subsection{Materials}

$\mathrm{TiO}_{2}$ (rutile type powder prepared by Toho Titanium Mfg. Co. and had a purity of $99.9 \%$ up) and $\mathrm{CaO}$ (guaranteed reagent grade powder prepared by Kanto Chemical Co.) were mixed in desired ratio in an agate mortor. One gram of mixed powder was pressed into a cube of $20 \times 5 \times 5 \mathrm{~mm}$.

\subsection{Apparatus}

The apparatus for melting of the specimen was an arc imaging furnace (made by Nippon Plasma Flame Co.) and is shown in Fig. 1.

The primary heat souce is a xenon arc lamp $(5 \mathrm{~kW}$, made by Ushio Electric $C_{0}$.) with ellipsoidal reflecting optics $\left(f_{1}=900 \mathrm{~mm}, f_{2}=110 \mathrm{~mm}\right)$. The light beam is reflected by the reflecting mirror and then turned by a plate mirror toward the reimaging mirror. The specimen was set on a holder at the focus of the reimaging mirror. $\mathrm{TiO}_{2}$ (m.p. $1,640^{\circ} \mathrm{C}$ ) could be melted by using this furnace.

The infrared absorption spectrum was examined by 


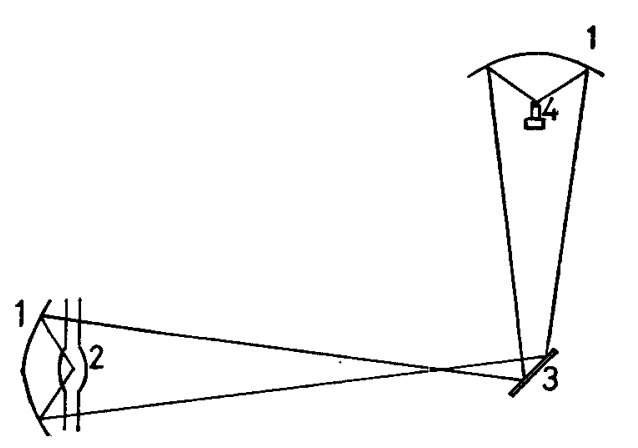

1: Reflecting ellipsoidal mirror

2 : Xenon arc lamp

3 : Reflecting plate mirror

4 : Melting sample

Fig. 1 Arc imaging furnace

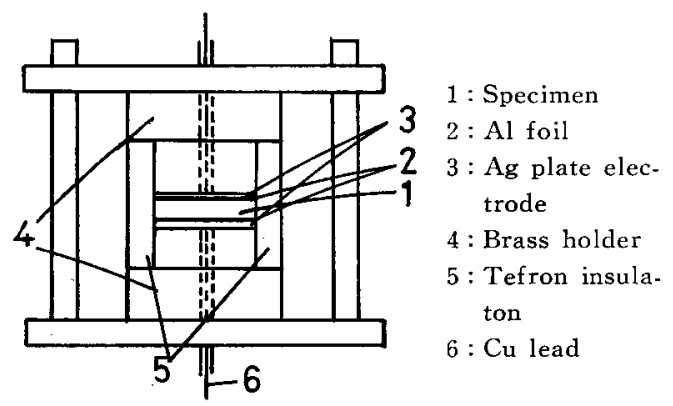

Fig. 2 Apparatus for dielectric constant measurement

the use of the infrared spectrometer (IR-G type made by Japan Spectroscopic Co.). The dielectric constant was measured by the universal bridge (TR-10 type made by Ando Electric Co.). The cell used for the measurement of the dielectric constant is shown in Fig. 2.

\subsection{Experimental procedure}

(a) Melting and quenching of the specimen: The mixed specimen of $\mathrm{TiO}_{2}$ and $\mathrm{CaO}$ set on the holder was melted by the radiation of the light beam. The temperature of the specimen was kept at a temperature $100 \sim 150^{\circ} \mathrm{C}$ higher than the melting point of the specimen. The duration time of the radiation was about $5 \mathrm{~min}$. Then the light beam was shut out and the specimen was quenched to the room temperature.

(b) Chemical analysis: Chemical analysis of calcium and titanium in the specimen was carried out as follows. About $100 \mathrm{mg}$ of the quenched specimen was taken in a platinum crucible and was fused with the addition of $\mathrm{KHSO}_{4}$. The fused mass was dissolved in a dil. $\mathrm{HCl}$ solution. Calcium and titanium contents were determined by the $\mathrm{CaC}_{2} \mathrm{O}_{4}-\mathrm{KMnO}_{4}$ titration method and the $\mathrm{Zn}-\mathrm{Hg}$ reduction method, respectively. (c) Infrared absorption spectroscopy: Infrared absorption spectrum was taken by using the $\mathrm{KBr}$ pellet method.

(d) Dielectric constant measurement: The quenched specimen was crushed into the powder under 300 mesh and about $0.1 \mathrm{~g}$ of the powder was pressed into a pellet which had a thickness of $0.5 \mathrm{~mm}$. The dielectric constant of the pellet was measured with a frequency of $1.592 \mathrm{~Hz}$ by the apparatus, which is shown in Fig. 2. During the measurement of the dielectric constant, the specimen was set in a dry box.

\section{Results}

\subsection{Chemical analysis of the quenched speci- mens}

In order to examine the stoichiometry of the quenched specimens from the melt, chemical analysis of $\mathrm{TiO}_{2}$ and $\mathrm{CaO}$ were made. Results obtained are listed in Table 1. $\mathrm{CaO}$ and $\mathrm{TiO}_{2}$ contents in the quenched specimens deviated $1 \sim 4$ mole $\%$ from those in the mixture. The analytical values of $\mathrm{CaO}$ were almost larger than the mixed values in every specimen. On the other hand, the analytical values of $\mathrm{TiO}_{2}$ were smaller than mixed values in every specimen. This fact suggests that a small amount of $\mathrm{TiO}_{2}$ might vaporize in the melted state.

Table 1 Chemical analysis data of quenched specimens

\begin{tabular}{c|c|c|c|c}
\hline \multirow{2}{*}{$\begin{array}{c}\text { Sample } \\
\text { No. }\end{array}$} & \multicolumn{2}{|c|}{$\begin{array}{c}\text { Mixed value } \\
\text { (mole } \%)\end{array}$} & \multicolumn{2}{|c}{$\begin{array}{c}\text { Analytical value } \\
\text { (mole } \%)\end{array}$} \\
\cline { 2 - 5 } & $\mathrm{CaO}$ & $\mathrm{TiO}_{2}$ & $\mathrm{CaO}$ & $\mathrm{TiO}_{2}$ \\
\hline 1 & 90.0 & 10.0 & 90.1 & 9.05 \\
3 & 80.0 & 20.0 & 80.6 & 18.9 \\
4 & 75.0 & 25.0 & 75.7 & 24.1 \\
5 & 70.0 & 30.0 & 72.8 & 27.8 \\
6 & 69.0 & 31.0 & 71.5 & 28.0 \\
7 & 68.2 & 31.8 & 70.4 & 28.7 \\
8 & 66.6 & 33.4 & 68.1 & 29.9 \\
9 & 57.2 & 40.0 & 60.7 & 37.8 \\
10 & 52.0 & 48.0 & 51.6 & 46.6 \\
11 & 50.0 & 50.0 & 50.7 & 48.3 \\
12 & 40.0 & 60.0 & 40.6 & 58.5 \\
13 & 30.0 & 70.0 & 29.9 & 68.5 \\
14 & 20.0 & 80.0 & 21.1 & 78.2 \\
15 & 10.0 & 90.0 & 12.7 & 86.1 \\
\hline & & & &
\end{tabular}

\section{$3.2 \mathrm{X}$-ray diffraction data of quenched speci-} mens

$\mathrm{X}$-ray diffraction data of the quenched specimens are listed in Table 2. Identified compounds in the specimens were $\mathrm{CaO}, \mathrm{CaO} \cdot \mathrm{TiO}_{2}, 3 \mathrm{CaO} \cdot 2 \mathrm{TiO}_{2}, 4 \mathrm{CaO}$. $3 \mathrm{TiO}_{2}$ and $\mathrm{TiO}_{2}$. Except for the specimen obtained 
Table 2 X-ray diffraction data of quenched specimens

\begin{tabular}{|c|c|c|c|c|c|}
\hline \multirow{2}{*}{$\frac{\text { Sample No. }}{1}$} & \multicolumn{5}{|c|}{ ldentified compounds } \\
\hline & $\mathrm{CaO}(\mathbf{s})$ & $3 \mathrm{CaO} \cdot 2 \mathrm{TiO}_{2}(\mathrm{~m})$ & & & \\
\hline 2 & $\mathrm{CaO}(\mathrm{s})$ & $3 \mathrm{CaO} \cdot 2 \mathrm{TiO}_{2}(\mathrm{~m})$ & & & \\
\hline 3 & $\mathrm{CaO}(\mathrm{m})$ & $3 \mathrm{CaO} \cdot 2 \mathrm{TiO}_{2}(\mathrm{~m})$ & & & \\
\hline 4 & $\mathrm{CaO}(\mathrm{m})$ & $3 \mathrm{CaO} \cdot 2 \mathrm{TiO}_{2}(\mathrm{~m})$ & & & \\
\hline 5 & $\mathrm{CaO}(\mathrm{m})$ & $3 \mathrm{CaO} \cdot 2 \mathrm{TiO}_{2}(\mathrm{~m})$ & & & \\
\hline 6 & $\mathrm{CaO}(\mathrm{m})$ & $3 \mathrm{CaO} \cdot 2 \mathrm{TiO}_{2}(\mathrm{~m})$ & & & \\
\hline 7 & & $3 \mathrm{CaO} \cdot 2 \mathrm{TiO}_{2}(\mathrm{~m})$ & & $\mathrm{CaO} \cdot \mathrm{TiO}_{2}(\mathrm{n} 1)$ & \\
\hline 8 & & $3 \mathrm{CaO} \cdot 2 \mathrm{TiO}_{2}(\mathrm{~m})$ & & $\mathrm{CaO} \cdot \mathrm{TiO}_{2}(\mathrm{~m})$ & \\
\hline 9 & & $3 \mathrm{CaO} \cdot 2 \mathrm{TiO}_{2}(\mathrm{~m})$ & & $\mathrm{CaO} \cdot \mathrm{TiO}_{2}(\mathrm{~m})$ & \\
\hline 10 & & & $4 \mathrm{CaO} \cdot 3 \mathrm{TiO}_{2}(\mathrm{~m})$ & $\mathrm{CaO} \cdot \mathrm{TiO}_{2}(\mathrm{~m})$ & \\
\hline 11 & & & & $\mathrm{CaO} \cdot \mathrm{TiO}_{2}(\mathrm{~m})$ & \\
\hline 12 & & & & $\mathrm{CaO} \cdot \mathrm{TiO}_{2}(\mathrm{~m})$ & $\mathrm{TiO}_{2}(\mathrm{~m})$ \\
\hline 13 & & & & $\mathrm{CaO} \cdot \mathrm{TiO}_{2}(\mathrm{~m})$ & $\mathrm{TiO}_{2}(\mathrm{~m})$ \\
\hline 14 & & & & $\mathrm{CaO} \cdot \mathrm{TiO}_{2}(\mathrm{~m})$ & $\mathrm{TiO}_{2}(\mathrm{~m})$ \\
\hline 15 & & & & $\mathrm{CaO} \cdot \mathrm{TiO}_{2}(\mathrm{~m})$ & $\mathrm{TiO}_{2}(\mathrm{~m})$ \\
\hline
\end{tabular}

at 50 mole $\%$ of $\mathrm{CaO}$, two phases were identified in quenched specimens.

From the X-ray diffraction data and the chemical analysis of the quenched specimens, identified phases and their boundaries are shown in Fig. 3 with referring to the liquidus presented by Roth ${ }^{10)}$. In this figure, the melting temperature of specimens in the present experiment are also shown.

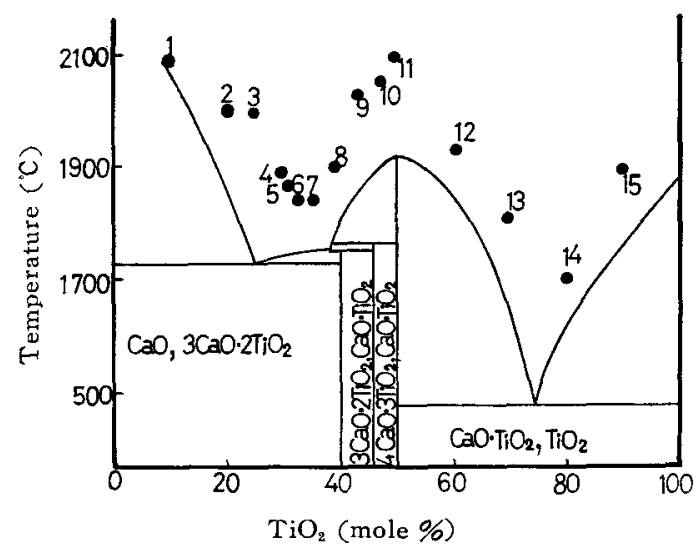

Numbers in this figure represent those of the sample in Table 1

The points indicate their melting temperatures

Fig. 3 Phase diagram of $\mathrm{TiO}_{2}-\mathrm{CaO}$ system

\subsection{Infrared absorption spectra}

The observed infrared absorption spectra of quenched specimens in the range of $800 \sim 400 \mathrm{~cm}^{-1}$ are shown in Fig. 4. The absorption band at about $540 \mathrm{~cm}^{-1}$ was observed in every specimen. In the specimen of $40 \sim 52$ mole $\%$ of $\mathrm{CaO}$, the absorption band at about $430 \mathrm{~cm}^{-1}$ was also observed.

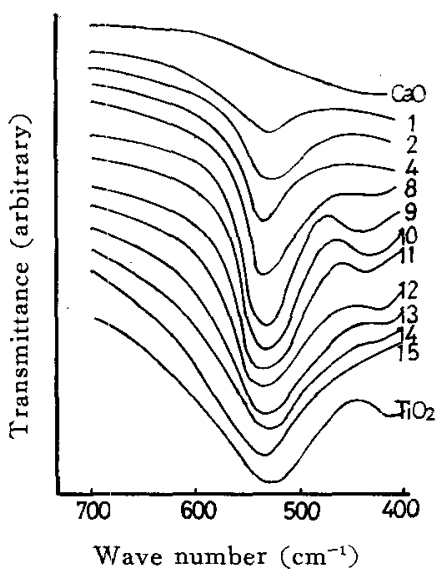

Numbers in this figure represent those of the sample in Table 1

Fig. 4 Infrared absorption spectra of $\mathrm{TiO}_{2} \cdot \mathrm{CaO}$ system

The infrared absorption spectra of quenched specimens stated above were similar to that of $\mathrm{TiO}_{2}$. It may be said that the atomic arrangement in these crystals are similar to that of $\mathrm{TiO}_{2}$. In the rutile type $\mathrm{TiO}_{2}$, six oxygen atoms are coordinated around a central titanium atom. Also in the perovskite type $\mathrm{CaO} \cdot \mathrm{TiO}_{2}$, six oxygen atoms are coordinated around a central titanium atom octahedrally.

The infrared absorption band at about $540 \mathrm{~cm}^{-1}$ was assigned to the $\mathrm{Ti}-\mathrm{O}$ stretching vibration and that at about $430 \mathrm{~cm}^{-1}$ was assigned to the Ti-O bending vibration in $\mathrm{TiO}_{6}$ octahedral configuration ${ }^{11}$. Therefore, $\mathrm{TiO}_{6}$ octahedral configuration may exsist in every specimen obtained by various $\mathrm{CaO}$ compositions.

\subsection{Dielectric constant measurement}

Dielectric constants of quenched specimen of each 
composition were measured. Being assumed that the pellet of the specimen is a mixture of a crystal and the air, the dielectric constant of the crystal was calculated from apparent value $(\varepsilon)$ by using eq. $(1)^{12}$

$$
\varepsilon=X_{1} \log \varepsilon_{1}+X_{2} \log \varepsilon_{2}
$$

where $\varepsilon_{1}, \varepsilon_{2}$ are the dielectric constants of the crystal and the air, and $X_{1}$ and $X_{2}$ are their volume fractions.

Apparent dielectric constants $(\varepsilon)$ and volume fractions of the crystal in the pellet $\left(X_{1}\right)$ are listed in Table 3 .

Table 3 Apparent dielectric constant $(\varepsilon)$ and volume fraction of the crystal in the pellet $\left(X_{1}\right)$

\begin{tabular}{c|c|c}
\hline Sample No. & $\varepsilon$ & $\mathrm{X}_{1}$ \\
\hline $\mathrm{CaO}$ & 5.30 & 0.61 \\
1 & 10.5 & 0.56 \\
2 & 7.20 & 0.44 \\
3 & 8.47 & 0.51 \\
4 & 6.80 & 0.55 \\
5 & 7.70 & 0.49 \\
6 & 8.30 & 0.51 \\
7 & 10.0 & 0.52 \\
8 & 8.70 & 0.60 \\
9 & 10.1 & 0.58 \\
10 & 17.2 & 0.67 \\
11 & 55.0 & 0.53 \\
12 & 13.5 & 0.66 \\
13 & 13.8 & 0.62 \\
14 & 15.6 & 0.64 \\
15 & 16.9 & 0.66 \\
$\mathrm{TiO}_{2}$ & 7.25 & 0.53 \\
\hline
\end{tabular}

The relation between the dielectric constant of the crystal and the composition of specimen is shown in Fig. 5. The dielectric constant of the specimen of 50 mole $\%$ of $\mathrm{TiO}_{2}$ was much larger than that of the

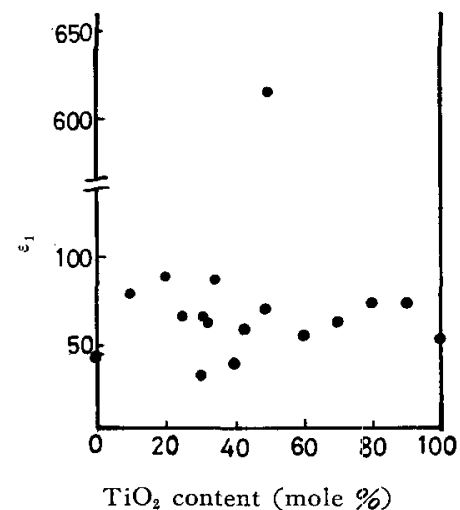

Fig. 5 Dielectric constants of $\mathrm{TiO}_{2}-\mathrm{CaO}$ system

other specimens.

\section{Discussion}

The infrared absorption band at about $540 \mathrm{~cm}^{-1}$ was observed in every specimen of $10 \sim 90$ mole $\%$ of $\mathrm{CaO}$. The absorption band may be due to $\mathrm{Ti}-\mathrm{O}$ stretching vibration in $\mathrm{TiO}_{6}$ octahedral configuration that was mentioned above. Therefore, every crystal observed in the present experiment may contain $\mathrm{TiO}_{6}$ octahedral configuration.

From the X-ray diffraction data, the existence of $\mathrm{CaO} \cdot \mathrm{TiO}_{2}, 3 \mathrm{CaO} \cdot 2 \mathrm{TiO}_{2}$ and $4 \mathrm{CaO} \cdot 3 \mathrm{TiO}_{2}$ were observed in $\mathrm{TiO}_{2}-\mathrm{CaO}$ system.

In the crystal structure of the perovskite type $\mathrm{CaO}$. $\mathrm{TiO}_{2}$, six oxygen atoms are coordinated around a cen-

Table $4 \mathrm{X}$-ray diffraction data of $3 \mathrm{CaO} \cdot 2 \mathrm{TiO}_{2}$, $4 \mathrm{CaO} \cdot 3 \mathrm{TiO}_{2}$ and $\mathrm{CaO} \cdot \mathrm{TiO}_{2}$

\begin{tabular}{|c|c|c|c|c|}
\hline & \multicolumn{3}{|c|}{$\mathrm{X}$-ray diffraction data } & \multirow{2}{*}{$\begin{array}{l}a_{\mathrm{O}}, c_{\mathrm{O}}(\mathrm{A}) \\
\text { from } \\
\text { ASTM } \\
\text { cards }\end{array}$} \\
\hline & $\begin{array}{l}2 \theta\left({ }^{\circ}\right) \\
\mathrm{CuK} \alpha \mid\end{array} d(\AA)$ & $h k l$ & $a_{\mathrm{O}}, c_{\mathrm{O}}(\AA)$ & \\
\hline \multirow{2}{*}{$3 \mathrm{CaO} \cdot 2 \mathrm{TiO}_{2}$} & $32.73|2.743|$ & 105 & $a_{0}=3.83$ & $a_{\mathrm{O}}=3.832$ \\
\hline & $47.40 \quad 1.916$ & 200 & $c_{0}=19.5$ & $c_{\mathrm{O}}=19.505$ \\
\hline \multirow{2}{*}{$4 \mathrm{CaO} \cdot 3 \mathrm{TiO}_{2}$} & $32.84 \mid 2.725$ & 107 & $a_{\mathrm{o}}=3.83$ & $a_{\mathrm{O}}=3.827$ \\
\hline & $\begin{array}{lll}47.43 & 1.915\end{array}$ & 200 & $c_{\mathrm{O}}=26.9$ & $c_{0}=27.147$ \\
\hline \multirow{2}{*}{$\mathrm{CaO} \cdot \mathrm{TiO}_{2}$} & $33.10 \mid 2.706$ & 044 & \multirow{2}{*}{$a_{0}=15.29$} & \multirow{2}{*}{$a_{0}=15.25$} \\
\hline & \begin{tabular}{l|l}
47.63 & 1
\end{tabular} & 008 & & \\
\hline
\end{tabular}

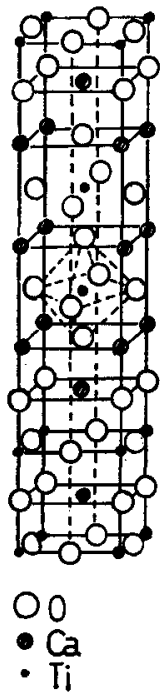

Fig. 6 Structure of $3 \mathrm{CaO} \cdot 2 \mathrm{TiO}_{2}$

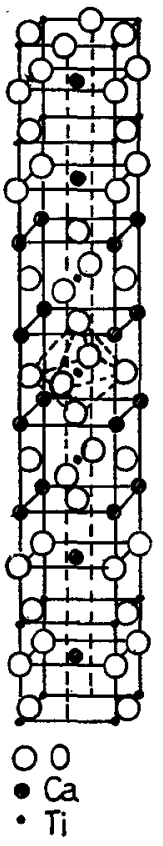

Fig. 7 Structure of $4 \mathrm{CaO} \cdot 3 \mathrm{TiO}_{2}$ 
tral titanium atom"1). Crystal systems and lattice parameters of $\mathrm{CaO} \cdot \mathrm{TiO}_{2}, 3 \mathrm{CaO} \cdot 2 \mathrm{TiO}_{2}$ and $4 \mathrm{CaO}$. $3 \mathrm{TiO}_{2}$ were determined as listed in Table 4. Lattice parameters of $3 \mathrm{CaO} \cdot 2 \mathrm{TiO}_{2}$ and $4 \mathrm{CaO} \cdot 3 \mathrm{TiO}_{2}$ almost agreed with these of $3 \mathrm{SrO} \cdot 2 \mathrm{TiO}_{2}$ and $4 \mathrm{CaO} \cdot 3 \mathrm{TiO}_{2}{ }^{13)}$, respectively. By reffering to the crystal structure of $3 \mathrm{SrO} \cdot 2 \mathrm{TiO}_{2}$ and $4 \mathrm{SrO} \cdot 3 \mathrm{TiO}_{2}{ }^{13)}$, the crystal structure of $3 \mathrm{CaO} \cdot 2 \mathrm{TiO}_{2}$ and $4 \mathrm{CaO} \cdot 3 \mathrm{TiO}_{2}$ are assumed to be as shown in Figs. 6 and 7 . The lattice parameters of the assumed structure agreed with the present experimental data. In these structure, $\mathrm{TiO}_{6}$ octahedral configuration exist. The infrared absorption spectra of the specimens containing these compounds may be attributed to the configuration.

The dielectric constant of the specimen that contained only $\mathrm{CaO} \cdot \mathrm{TiO}_{2}$ was much larger than that of the other specimen. It is considered that the dielectric constant relates to the crystal structure. The crystal structure of $\mathrm{CaO} \cdot \mathrm{TiO}_{2}$ is a pseudo-cubic as shown in Table 4. This structure is similar to that of $\mathrm{BaO}$. $\mathrm{TiO}_{2}$ which is known to be ferromagnetic. The dielectric constant of $\mathrm{CaO} \cdot \mathrm{TiO}_{2}$ formed in the present experiment is considerably large, although the crystal of cubic system is non-polar and has no spontaneous polarization. Therefore, the crytal of $\mathrm{CaO} \cdot \mathrm{TiO}$, formed in the present experiment may be distorted similarly in the case of $\mathrm{BaO} \cdot \mathrm{TiO}_{2}$.

Quenched specimens except for the specimen at 50 mole $\%$ of $\mathrm{CaO}$ were mixtures of cubic and tetragonal systems or those of pseudo-cubic and tetragonal systems. Therefore, the dielectric constants of quenched specimens except for $\mathrm{CaO} \cdot \mathrm{TiO}_{2}$ were considerably smaller than that of $\mathrm{CaO} \cdot \mathrm{TiO}_{2}$.

(Received Dec. 20, 1971)

\section{Literatures :}

1) T. Noguchi, M. Mizuno, W.M. Coun, Solar Energy 11. 145 (1967).

2) T. Noguchi, M. Mizuno, Bull. Chem. Soc. Japan 41, 1583 (1968).

3) T. Noguchi, T. Okubo, O. Yonemochi, J. Am. Ceram. Soc. 52, 178 (1967).

4) T. Noguchi, M. Mizuno, Bull. Chem. Soc. Japan 41, 2895 (1968).

5) A. Rounaet, Cempt. Rend. 267, Ser. C, 395 (1968).

6) A. Rounaet, M. Foex, ibid. 267, Ser. C, 873 (1968).

7) T. Noguchi, M. Mizuno, Kogyo Kagaku Zassi 70, 843 (1967).

8) T.S. Laszlo, "Image Furnace Techniques", p. 132 (1965), John Wiley \& Sons, N.Y.

9) R.C. Devries, R. Roy, E.S. Osborn, J. Phys. Chem. 58, 1069 (1954).

10) R.S. Roth, J. Res. Nat. Bur. Std. 61, 437 (1958).

11) J.T. Last, Phys. Rev. 105, 1740 (1957).

12) W.D. Kingery, "Introduction to Ceramics", p. 719 (1960), John Wiley \& Sons, N.Y.

13) S.N. Rudlesden, P. Popper, Acta Cryst. 11, 54 (1958)

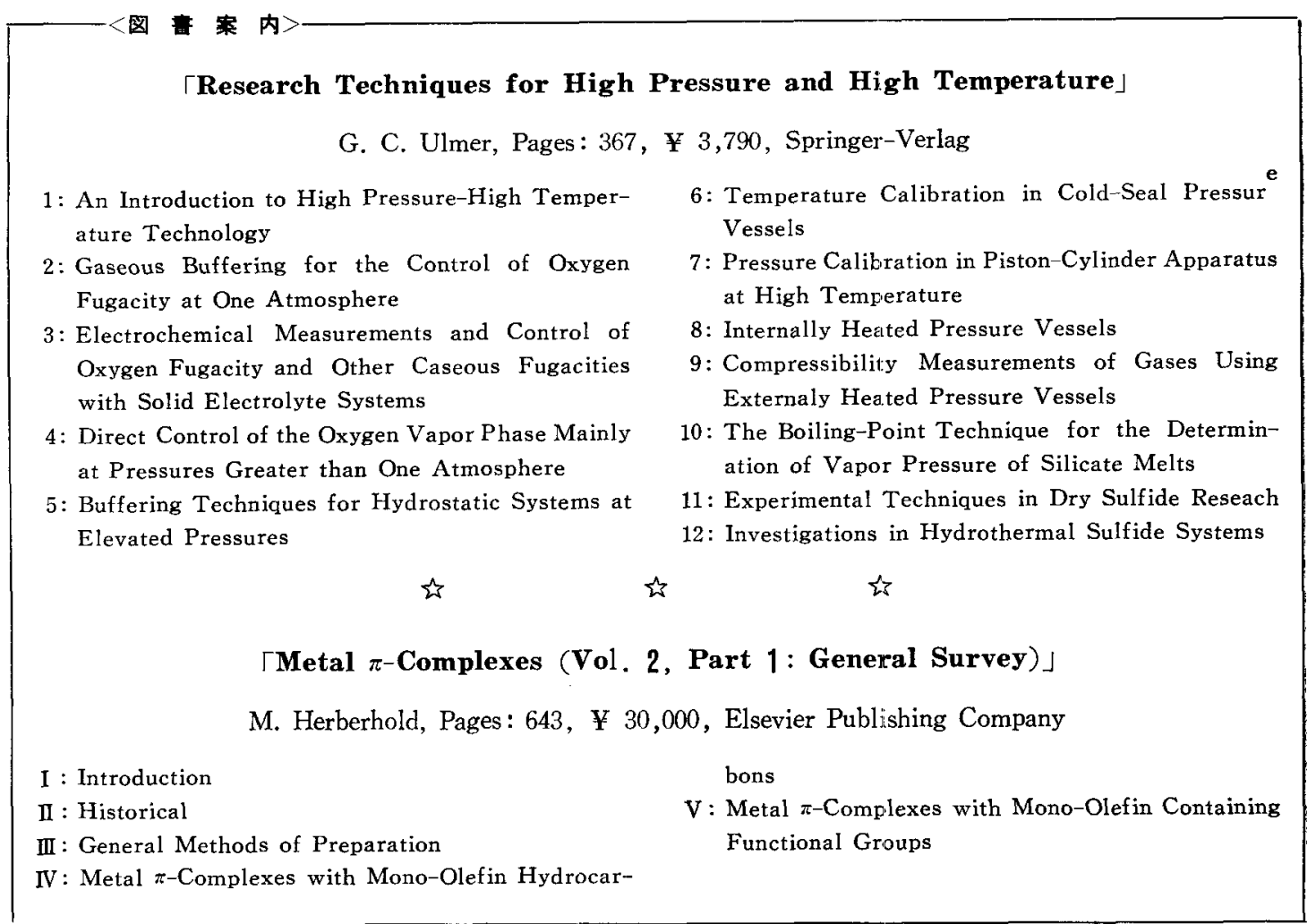

